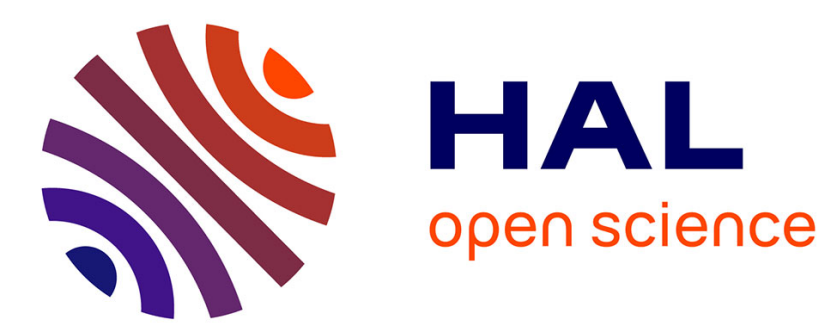

\title{
Dudley Carleton and 'The Libertie of Old Fashioned Poetrie' on 8 November 1596 \\ Guillaume Coatalen
}

\section{To cite this version:}

Guillaume Coatalen. Dudley Carleton and 'The Libertie of Old Fashioned Poetrie' on 8 November 1596. Notes and Queries, 2009, 56 (4), pp.563-566. hal-00599760

\section{HAL Id: hal-00599760 \\ https://hal.science/hal-00599760}

Submitted on 11 Jun 2011

HAL is a multi-disciplinary open access archive for the deposit and dissemination of scientific research documents, whether they are published or not. The documents may come from teaching and research institutions in France or abroad, or from public or private research centers.
L'archive ouverte pluridisciplinaire HAL, est destinée au dépôt et à la diffusion de documents scientifiques de niveau recherche, publiés ou non, émanant des établissements d'enseignement et de recherche français ou étrangers, des laboratoires publics ou privés. 


\title{
Dudley Carleton and 'the libertie of old fashioned poetrie' on 8 November 1596
}

Unpublished SP 12/260, \#148, dated 8 Nov 1596, is one of the earliest extant letters from Dudley Carleton to his lifelong friend and correspondent John Chamberlain ${ }^{1}$ whose own earliest published letter to Dudley was written June 11 1597. ${ }^{2}$ The transcription is diplomatic and angle brackets enclose authorial insertions.

\author{
Mr : Dudley Carlton Oxford \\ 1596
}

To his verie louing frend Mr John Chamberlain at Doct : Gilbert ${ }^{3}$ his house on $\mathrm{S}$ : Peters hill ${ }^{4}$ geue these :

189

Sr, I thanck you for hauing me in so good remembrance as to send thes Sonetts which I did much desire, and for to acquainting me with your newes owt of France for which I did more then vsuallie long. The verses please me the more in that they treat of vnaccosta $=$ med matter, and doe make that the subiect of

\footnotetext{
${ }^{1}$ The earliest are SP 12/256, \#12 (29 Feb 1595), SP 12/255, \#74 (5 Aug 1595), SP 78/37, \#105 (22 Mars [1596]), SP 12/259, \#195 (8 Aug 1596).

${ }^{2}$ Letters written by John Chamberlain during the reign of Queen Elizabeth, ed. Sarah Williams (London, 1861), 1-5.

${ }^{3}$ William Gilbert (1540-1603), physician to Queen Elizabeth and author of the first treatise on magnetism. 'His will mentions one godson, and two 'good ffrends', a $\mathrm{Mr}$ Harwood and, more significantly, John Chamberlain. Chamberlain, the famous gossipy correspondent, lodged with Gilbert in Wingfield House between c.1595 and 1601, and mentioned him respectfully' Stephen Pumfrey, 'Gilbert, William (1544?-1603)', Oxford Dictionary of National Biography (Oxford, 2004).

${ }^{4}$ 'By 1595 Gilbert had acquired and moved into Wingfield House in St Peter's Hill, a substantial property near St Paul's Cathedral possibly inherited from his stepmother' Pumfrey, $O D N B$.
} 
Poetrie to which loosenes which doth accompanie the best wittes cannot learne to frame yt self. For in this much writing age that Poett is in great streites who tieth himself to such a matter that he cannot vse the libertie of old fashioned poetrie as to speake of Goddes, Goddisses, Muses and Cupids, and therfore is the more to be liked by how much the more he is debarred of common helper.

15 I imagine your liking towardes these to be as great as mine, wherfore I haue returned againe these English poemes, accompanied with your French discourse of a Spanish patissier . which discourse I haue communicated with some of my vniuersitie frendes, men of easye credit which beleeue yt better then I doe and are exceedinglie delighted with the noueltie . yt is a hard thing for anie child to know his own father, else might I be brought to indiferent credence in this cause. I am gladd to heare of Mr Euers so neere approche hoping vppon his arriuall to heare more con= cerning Mr Mildmay . for I know not how I am fallen into a more then earnest longing after his seruice whilst he is in France. And 30 though I might be iudged to be distasted with such kind of course, by the vnhappie success of my last iorneye, yet that hath geuen me a greater edge, and made me like to those gamesters who account yt a good sighne to loose at first. Besides I haue reapt so much yt iorneye verso

that though yt hath not sett me in such forwardness as to make me haue a good conceipt of my self of vnusuall fittnes to such kind of seruises, yet yt

40 hath worked so much with me as to make me attmost vnfitt for anie other kind of course . for through dissuetude I find my self to be behind hand with diuerse of my old companions in ordinarie $\mathrm{s}<\mathrm{c}>$ holers exersises, though I can better tell how the $\mathrm{k}$. of

45 France lookes then they. I praye you yf anie thing come by Mr Euers which concernes me in this cause

42 dissuetude] An obscure word for which there are only two later occurrences in the OED on CD-ROM (Oxford, 1992): '1639 Spottiswood Hist. Ch. Scot. vi. (1677) 464 His long dissuetude of the Country-language made him unuseful at first. 1755 Johnson s.v. Disuse 1, Cessation of use, dissuetude; want of practice'. 
lett me heare from you, yf nothing, yet lett me heare from you, and ben lett me entreate you not to be sparing of your aduise, for I relie more vppon your iudgment then anie others. I haue heard you often say you did beare < take $>$ small pleasure in writing but that you lou'd to read a long letter, yet I dowbt I haue trobled you so much at this present that yf I should be anye longer I should trie the vttermost of your patience. Wherfore remembring my due com= mendations most hartelie vnto you, I wish you all wellfare. from Oxford. Nouember 8 1596.

yours allwaies most assuredlie

\section{Dudley Carleton}

In the letter Dudley thanks his friend for English sonnets and the 'French discourse of a Spanish patissier, ${ }^{5}$ a story he has shown to his university friends with great success. The second half of the letter is devoted to his career prospects as a diplomat in France. He hopes Mr Evers, Sir Peter Evers, ${ }^{6}$ will help him get a position with Mildmay, the ambassador to France, and boasts he knows the French King far better than any other student. He recalls a recent unhappy experience on the Continent, when he failed to secure employment at Mildmay's service, and shows little motivation for academic exercises he has not practiced for long. Though the sonnets are not quoted, the letter offers significant literary criticism which throws light on poetic taste in late 1596 .

Dudley Carleton came up to Christ Church from Westminster, ${ }^{7}$ a school

\footnotetext{
${ }^{5}$ Le Patissier de Madrigal en Espaigne, estimé estre Dom Carles, fils du roy Philippe. A Paris, par Jean Le Blanc, ruë Sainct-Victor, au Soleil d'or. 1596. In-8. Another edition was printed in Poitiers in the same year.

6، of Lincolnshire, was knighted May 11, 1603', Letters 1861, 4, note d.

${ }^{7}$ I am grateful to Judith Curthoys, the archivist of Christ Church college, Oxford, for the following information: Dudley Carleton came up to Christ Church from Westminster School in 1591. There were fourteen other boys who started here that year as well, including two more from Westminster. These were Thomas Lewis, who became a chaplain in the cathedral and then rector of Edlington parish in Yorkshire, and John Ireland who became the headmaster of a grammar school in Croydon, Surrey. His other contemporaries were: George Brook, about whom we know very little; Robert Drew, who became a Member of Parliament; Thomas James, who, like most graduates at Christ Church, became a clergyman; Robert Killigrew, who was an ambassador, and Member of Parliament; John Leigh, who became a fellow of All Souls College and then treasurer to the diocese of Salisbury; William Warmstry, who became registrar to the diocese of Worcester; Thomas White, the founder of Sion College; and George Brook, Philip Pratt, Edmund Turner, Edward Waring, and Edward Waterhouse about whom we know nothing. 'Killigrew was a cosmopolitan and cultured man. When the Dutch diplomat and poet Constantijn Huygens
} 
where Camden promoted the writing of verse in the vernacular. ${ }^{8}$ Ben Jonson, Dudley's contemporary at Westminster, profited immensely from this early practice. ${ }^{9}$ In another letter in Latin (SP 12/256, \#122) addressed to Chamberlain, Dudley complains that Mars leaves little time to Mercury, ${ }^{10}$ which suggests a keen interest in poetry. Many Jacobean and Caroline verse miscellanies in manuscript circulated at Christ Church, ${ }^{11}$ and though no similar manuscripts from the 1590s survive, vernacular verse was already flourishing in college, as shown by the number of poets and playwrights writing in English enrolled at Christ Church - among them Wood singles out Philip Sidney, George Peele and Richard Carew in his history of the university. ${ }^{12}$ The letter writer notes this is a much writing age, which seems to be a commonplace, judging by Donne's 'Satire 2' (1. 23), 'And they who write, because all write'. ${ }^{13}$ On 8 August 1596 (SP 12/259, \#195), Dudley asked Chamberlain to return a manuscript copy of 'D. Ædes', i.e. Richard Eedes's or Edes's Iter Boreale, ${ }^{14}$ 'because it is not mine owne but borrowed'. Edes's work, which was never printed, enjoyed a high reputation at Oxford, it seems, for it occurs in a list of writers of the university in the early seventeenth century Bodleian MS misc Eng d 28, p. 647, an Oxford commonplace book, ${ }^{15}$ and was praised by Meres in his Palladis Tamia (1598) as one of the best for tragedy (p. 283). ${ }^{16}$ He too was educated at Westminster.

stayed with Killigrew in 1622 he was introduced by his host to many of London's cultural élite, including John Donne, Sir Francis Bacon, the musician and painter Nicholas Lanier, the lutenist Jacques Gaultier, and the lens-grinder Cornelius Drebbel' Alastair Bellany, 'Killigrew, Sir Robert (1579/80-1633)', Oxford Dictionary of National Biography (Oxford, 2004).

${ }^{8}$ Richard Mulcaster, the shoolmaster who encouraged his pupils to compose English verse, was another Christ Church man.

${ }^{9}$ Like other Westminster poets after him - Richard Corbett, George Herbert, Henry King, Abraham Cowley, John Dryden - Jonson benefited deeply from the school's traditions of rhetorical and classical training, and, in particular, from the exercise of rendering Greek and Latin verse and prose into their equivalent English forms. Camden, who had a good knowledge of earlier English poetry, seems also to have encouraged his boys to write verses of their own in English.' Ian Donaldson, 'Jonson, Benjamin (1572-1637)', Oxford Dictionary of National Biography (Oxford, 2004).

${ }^{10}$ 'nec per Martem locus est Mercurio'.

${ }^{11}$ See M. Hobbs, Early Seventeenth-Century Verse Miscellany Manuscripts (Aldershot, 1992).

${ }^{12}$ Historia et Antiquitates Univ. Oxon., (1674), Lib. II., 262-84.

${ }^{13}$ John Donne, Major Works, ed. J. Carey (Oxford, 1990).

${ }^{14} \mathrm{BL}$ Add. 30352 is an early 17 th $\mathrm{C}$ copy.

${ }^{15}$ See G. Coatalen, 'Shakespeare and other 'Tragicall Discourses' in an Early Seventeenth-Century Commonplace Book from Oriel College, Oxford' 120-64, in New Texts and Discoveries in Early Modern English Manuscripts, ed. Peter Beal, English Manuscript Studies 1100-1700, Vol. 13 (London, 2007).

${ }^{16}$ BL Add. 41499 A, f.13 contains 'Epilogus Cæsaris interfecti', beg. 'Egit triumphum Cæsar'. 'Cæsar Interfectus' was acted at Christ Church, Oxford, probably in Feb. 1582, and the Epilogue is assigned to Richard Eedes in Bodl. MS. Top. Oxon. e. 5, f. 359, from which it was printed by F. S. Boas, University Drama in the Tudor Age, 1914, pp. 164, 
SP 12/260, f.148 proves there was a strong demand at Oxford for new literary material from London. Interestingly, Carleton kept the English sonnets for himself, perhaps because he did not want other students to use them to catch a patron's attention. He is slightly patronising towards his university friends who are 'men of easye credit', i.e. of less refined literary tastes.

Carleton's correspondence contains a substantial amount of literary criticism. His remarks on Bastard's epigrams ${ }^{17}$ and on the theatre ${ }^{18}$ are wellknown. He praises the sonnets - sonnets in the modern sense of the word or short poems - for their 'vnaccostamed matter' or original topic. The letter suggests a change in poetic taste, from the 'libertie of old fashioned poetrie as to speake of Goddes, Goddisses, Muses and Cupids' to the deliberate exclusion of the 'common helper'. He notes a poet's reputation is now measured according to his ability to write verse without tapping into the reservoir of ancient myths. It is precisely because of their 'loosenes', or freedom from restraint, that the 'best wittes' cannot frame their verse to the subject of poetry. Dudley goes on by defining loosenes as the refusal to rely on mythological commonplaces, 'the libertie of old fashioned poetrie'. Thus, he opposes two forms of freedom, one negative - 'loosenes' the other positive - the use of ancient myths. To find the relevant information, poets could go to an annotated Homer, Virgil or Ovid, but they were more likely to consult one of the handy compendiums assembled by Italian mythographers. ${ }^{19}$

Paradoxically, Dudley implies poetic conventions are necessary to deal with 'vnaccostamed matter'. Early modern English writers, who followed Latin authorities in the matter - notably Lucius Annæus Seneca's 84th of his Epistulce morales ${ }^{20}$ believed there was no contradiction between originality

165 (cf. Chambers, The Elizabethan Stage, iii, p. 84). f. ii b. The same ms, f. 14, has The second Woodstock Entertainment, dated in the margin '1592 September 20'. The first six sections are new, the last six correspond to artt. $v-x$ in Chambers. As follows:-(1) 'The knight that had Charge of the groue', beg. 'Ladye or queene or both'. f. 12;-(2) 'The second knyghts Complaynt', beg. 'What troops are theise'. Attributed to Dr [Richard] Edes in Petyt MS. 538, 43, f. 300b, and there entitled 'The melancholie Knights complaint in the wood' $=$ art. xi in Chambers, op. cit., iii, p. 406. f. 12. [British Library online Manuscripts Catalogue]

${ }^{17} \mathrm{CSP}$ dom., 1580-1625, addenda, 385.

${ }^{18}$ See his letter from London, SP 14/12, \#6, January 7, 1604/5 printed in Dudley Carleton to John Chamberlain 1603-1624, Jacobean Letters, ed. M. Lee, Jr. (New Brunswick, 1972), 66-7, in which he reports on Jonson's Masque of Blackness.

${ }^{19}$ See Jean Seznec, The Survival of the Pagan Gods: The Mythological Tradition and Its Place in Renaissance Humanism and Art (Princeton, 1953), 312-13, Mindele Anne Treip, Allegorical Poetics $\&$ the Epic. The Renaissance Tradition to Paradise Lost (Kentucky, 1993), 28-41. Bocccacio's Genealogice (Venice, 1494) was the first major compendium. Others included Vincenzo Cartari, Le Imagini con la spositione de $i$ dei de gli antichi (Venice, 1571), Natalis Comes, Mythologice sive explicationum fabularum libri decem (Venice, 1567), and Lilio Gregorio Giraldi, De deis gentium (Basel, 1548).

${ }^{20}$ See B. Vickers, English Renaissance Literary Criticism (Oxford, 1999), 24-5. 
and imitation. On the contrary, the only way to be original was to 'make our own' (Ep. Mor. 84, 8) ${ }^{21}$ ancient models: like Ovid, Horace and Virgil, poets should 'speake of Goddes'. When Puttenham defines 'The subiect or matter of Poesie' he states that 'the chief and principall is: the laud honour $\&$ glory of the immortal gods' ${ }^{22}$ In the following chapter, when he reviews Latin and Greek poetic genres, he begins with the 'long histories of the noble gests of kings \& great Princes entermedling the dealings of the gods, halfe gods or Heroes of the gentiles', quoting Homer and Virgil as 'chief and most ancient'. ${ }^{23}$ The prestige of ancient myths is undeniable as shown by Chapman's unequivocal 'Of all bookes extant in all kinds, Homer is the first and best' ${ }^{24}$

Marlowe's and Spenser's poetry written before 1596 is certainly full of pagan gods and muses. So is Sidney's, whose verse was still very much in favour in the 1590s after his death in $1586 .{ }^{25}$ The change in taste probably coincides with the rise of metaphysical poetry, a strong reaction against classical myths, as illustrated by Donne's early verse which rarely alludes to pagan gods.

Guillaume Coatalen, Université de Cergy-Pontoise

\footnotetext{
${ }^{21}$ Vickers 25.

${ }^{22}$ George Puttenham, The Arte of English Poesie, eds. Gladys Doidge Willcock and Alice Walker (Cambridge, 1936), 24.

${ }^{23}$ Arte of English Poesie, 25.

${ }^{24}$ Chapman's Homer, ed. Allardyce Nicoll (Princeton, 1998), 14.

${ }^{25}$ See H. R. Woudhuysen, Sir Philip Sidney and the Circulation of Manuscripts 15581640 (Oxford, 1996).
} 